Ю.Г. Якусевич, В.В. Тришин, З.Я. Дорофєєва

Державний університет інфраструктури та технологій, Ізмаїл

\title{
ПОБУДОВА НАВІГАЦІЙНОЇ СИСТЕМИ СУДНА НА ОСНОВІ СУЧАСНИХ ІНФОРМАЦІЙНИХ ТЕХНОЛОГІЙ
}

У статті розглядається можливість застосування інформаційних технологій у моніторингу руху суден для пошуку нових рішень на основі концепції електронної навігаџії. Впровадження електронної навігації вимагає адаптації існуючих систем навігації та зв'язку до иүієї нової концепиії. Розглядаються підходи до розробки систем підтримки прийняття рішень на основі навігаційно-інформаційної системи ECDIS через вимоги електронної навігації. 3 огляду на велику кількість пристроїв і систем, щзо використовуються в навігачіï, адаптація навігаџійно-інформаційної системи ECDIS до вимог електронної навігачії має сенс тільки при ретельному розумінні потреб користувача. Шляхом інтеграції всієї доступної інформації, ї̈ організації в базі даних і представлення ї̈ певним чином створюється платформа для прийняття рішень в повсякденній навігації судна з використанням системи підтримки прийняття рішень. Оскільки застосування навігаиүійно-інформаційної системи ECDIS на борту стало обов'язковим і основним навігачійним пристроєм судна, адаптачія до вимог електронної навігачії означає перетворення ї̈ в базовий компонент відповідної системи підтримки прийняття рімень.

Ключові слова: Electronic Chart Display and Information System, навігачійно-інформаційні системи, електронні карти, інформаційна технологія, система підтримки прийняття рішень, морське судно.

\section{Вступ}

Постановка проблеми. Інформаційнокомунікаційні технології знаходять застосування у всіх галузях виробництва, включаючи і транспорт, забезпечуючи підвищення їх ефективності. Одним із прикладів впровадження цих технологій на судах стали навігаційно-інформаційні системи з електронними картами (НIC). Найбільш ефективний представник суднових НIC - це система Electronic Chart Display and Information System (ECDIS). Система ECDIS стала обов'язковою на борту суден і всі судна, що підпадають під дію СОЛАС74, повинні бути оснащені цією системою [1].

Сама система розроблена як пристрій, який об'єднує різні навігаційні дані та представляє їх у вигляді корисної інформації на електронній карті Electronic Navigational Chart (ENC). Поява системи такої складності і широкого діапазону можливостей, при збереженні всіх інших навігаційних пристроїв і систем на борту, сприяє більшій безпеці судноплавства і кращому контролю судноплавства.

На даний час одним 3 підходів до підвищення безпеки мореплавання є підхід, заснований на використанні інформаційних технологій в рамках концепції електронної навігації. У зв'язку з розвитком інформаційних технологій на основі електронної навігації і необхідністю більш високого ступеня інтеграції та обміну інформацією виникає необхідність в адаптації HIC ECDIS до концепції електрон- ної навігації. 3 цієї причини необхідно проаналізувати потреби і вимоги, які повинні бути виконані для успішного застосування HIC ECDIS в якості центральної частини концепції електронної навігації на борту судна в рамках відповідної інформаційної технології як базового елементу системи підтримки прийняття рішень (СППР) в області безпеки навігації [2].

За допомогою HIC ECDIS карти ENC вже були успішно інтегровані з супутниковою системою позиціонування GNSS, радаром ARPA і системою ідентифікації суден AIS (рис. 1). Система також дозволяє інтегрувати різні типи навігаційного обладнання.

В якості основних проблем можна виділити такі:

- карти ENC ще не мають 100\% глобального покриття. Не всі райони Світового Океану покриті картами ENC. У тих районах, де немає покриття картами ENC, дозволяється використання НIC ECDIS в режимі RCDS Mode (Raster Chart Display System Mode). Це означає, що замість офіційних векторних карт (ENC) в HIC ECDIS можна використовувати офіційні растрові карти (RNC). Але при експлуатації HIC ECDIS в режимі RCDS Mode растрові карти повинні використовуватися спільно 3 відповідними відкоригованими паперовими картами. Це визначає резолюція IMO MSC.232 (82) "Adoption of the revised performance standards for ECDIS"; 
- недоліки існуючого гідрографічного стандарту S-57 (в даний час використовується для представлення даних на морських картах ENC) для використання в електронній навігації (відсутні можливості використання морської інформації в картах S-57). Міжнародна гідрографічна організація (International
Hydrographic Organization (IHO)) розробила новий стандарт S-100 в якості універсальної моделі гідрографічних даних, яка дозволить використовувати зображення 3 карт, класифікацію морського дна, батиметрія високої щільності, 3D-дані, онлайноновлення і т. д.
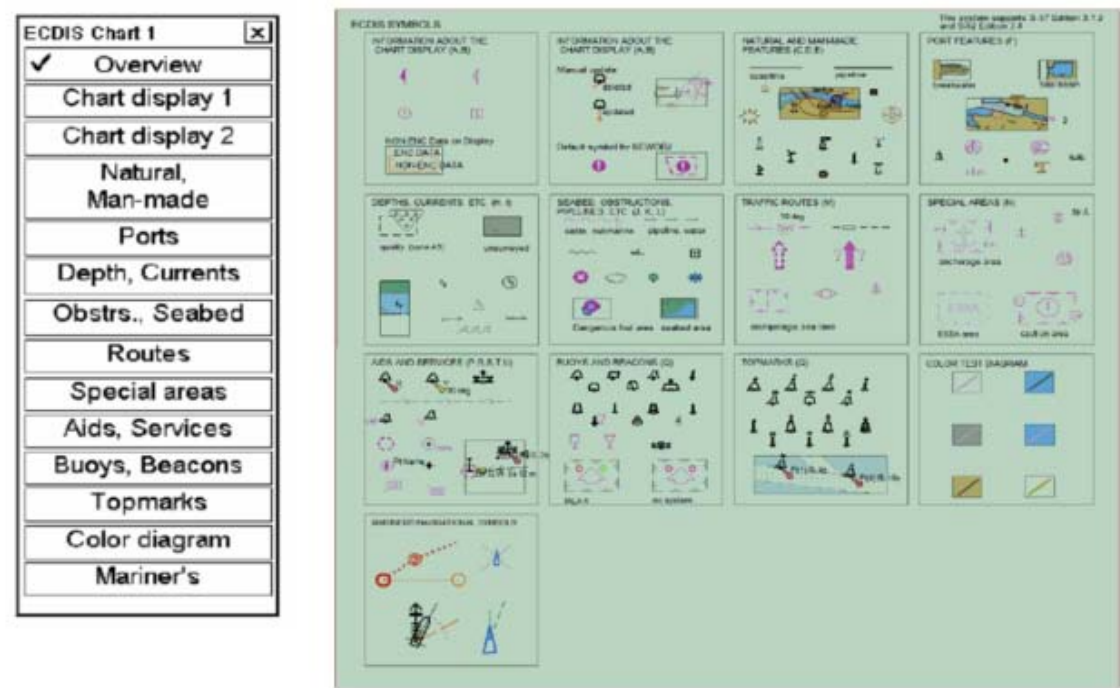

Рис. 1. Приклад меню для роботи з картами в HIC ECDIS

Джерело: розроблено авторами.

Мета статті. Розробка пропозицій щодо побудови СППР для безпеки навігації в рамках відповідної інформаційної технології на базі HIC ECDIS, які становлять основу практичної реалізації електронної навігації.

\section{Виклад основного матеріалу}

При розробці СППР для безпеки навігації в рамках інформаційної технології на базі HIC ECDIS виділимо такі основні їі етапи:

1) визначення, на основі аналізу характеристик і джерел даних, найголовніших видів інформації, що використовуються в електронній навігації;

2) аналіз вимог до оснащення та архітектури HIC ECDIS;

3) адаптація HIC ECDIS до вимог електронної навігації;

4) формування архітектури СППР для безпеки навігації на базі HIC ECDIS.

Доступність і своєчасність інформації - основні параметри концепції електронної навігації. За характеристиками і джерелами даних, що циркулюють в СППР для безпеки навігації на базі НІС ECDIS, інформацію можна розділити на:

- інформацію суднових датчиків (швидкість, курс, положення, вітер, глибина, ROT, індикація кута повороту керма);

- інформацію про рух від берегової системи управління рухом суден (Vessel Traffic Service (VTS)) (щільність руху, коридори руху, інформація SAR, інформація про порти, обмін маршрутами, логістична інформація);

- інформацію про погоду та атмосферу (звіти про погоду, поточні звіти, льодові звіти, звіти про вітер, звіти про припливи);

- інформацію для запобігання зіткнень і посадки на мілину (об'єкти ARPA, інформація AIS, відображення оптимального маршруту, характеристики судна, зонів райони, що охороняються, археологічні розкопки).

Кожна частина інформації сама по собі представляє лише одну зі змінних, практична цінність якої визначається тільки через інтеграцію 3 іншою зовнішньою або внутрішньою інформацією. Вся інтегрована інформація формує набір взаємозалежних і змінюваних у часі даних, які дають нові можливості подання і використання відповідної інформації для цілей навігації в рамках концепції електронної навігації.

Згідно з конвенцією СОЛАС, на всіх пасажирських і торгових судах, що здійснюють міжнародні рейси за пропонованим розкладом, повинна бути встановлена HIC ECDIS. Правило для пасажирських суден діє 31 липня 2014 року, а для вантажних суден 31 липня 2018. Впровадження HIC ECDIS, згідно 3 поправками до СОЛАС MSC 282 (86) [3-4], було реалізовано в сім етапів:

1. Липень 2012: Всі нові пасажирські судна більше 500 тонн і нові танкери більше 3000 тонн.

2. Липень 2013: Всі нові вантажні судна більше 10000 тонн

3. Липень 2014: Всі нові вантажні судна понад 
3000 тонн і існуючі пасажирські судна більше 500 тонн.

4. Липень 2015: Існуючі танкери більше 3000 тонн.

5. Липень 2016: Існуючі вантажні судна більше 50000 тонн.

6. Липень 2017: Існуючі вантажні судна від 20000 тонн до 50000 тонн.

7. Липень 2018: Існуючі вантажні судна від 10000 до 20000 тонн.

При цьому IMO регулює мінімальні вимоги, яким HIC ECDIS повинна задовольняти, щоб бути схваленою IMO відповідно до її резолюції MSC.232 (82), яка застосовується для систем, встановлених після 1 січня 2009 року:

- можливість використання HIC ENC в стандартному форматі S-57 (з переходом на більш новий формат S-100);

- представлення графіків в форматі специфікації кольору і символів S-52;

- підтримка основних навігаційних функцій (VRM, EBL, планування маршруту, моніторинг маршруту);

- підтримка інформації, отриманої від інших навігаційних систем і пристроїв;

- наявність засобів управління і генерації аварійних сигналів 3 попередженням і візуальною індикацією несправності;

- окреме електроживлення;

- підтримка резервного копіювання.

CППР для безпеки навігації на базі HIC ECDIS вимагає коригування концепції електронної навігаціï, оскільки HIC ECDIS є центральним для користувача інтерфейсом для обміну даними та зв'язку між судами і береговими пунктами. HIC ECDIS підтримує подання даних через три основних рівня даних (базовий, стандартний і повний), що дозволяє користувачеві вибирати різні рівні даних відповідно до власних уподобань, починаючи від базового до подання всіх доступних даних та інформації.

Інтеграція інформації, яку система отримує із зовнішніх джерел, включає створення додаткових рівнів даних, які використовуються в СППР для доступу до метеорологічної, ситуаційної, навігаційної та іншої інформації, наприклад, MSI, інформації від VTS, інформації від служб матеріальнотехнічного забезпечення, відображення об'ємних зон, 3D-уявлення і багато іншого. Поточні можливості, які підтримує HIC ECDIS, необхідні для розширених функцій, необхідних для задоволення потреб електронної навігації в рамках СППР [7]. На даний момент вони обмежуються моделлю представлення даних S-57, а в рамках розроблюваної СППР використовується модель гідрографічних даних S-100 3 розширеними можливостями відображення, використання та обміну даними.
Використання моделі представлення даних S-100 дозволяс користувачеві зберігати всі функції рівня, існуючі в класичній конфігурації HIC ECDIS, 3 підтримкою функцій, які будуть обслуговувати електронну навігацію, наприклад:

- управління інтегрованою навігаційною системою і центральною сигналізацією судів;

- контроль за рухом суден і поточною ситуацією на морі;

- моніторинг навігаційної, метеорологічної та гідрографічної інформації від датчиків;

- створення і планування маршруту;

- матеріально-технічна підтримка, служби SAR, інші постачальники послуг;

- обмін даними в реальному часі між користувачами;

- автоматичне створення звітів про стан судна в цілому і його окремих систем;

- онлайн-оновлення карт ENC та інших оновлюваних навігаційних систем;

- доступ в Інтернет в цілому і до різних Інтернет-послуг зокрема.

HIC ECDIS - це потужна навігаційна система зі складним програмним забезпеченням і складним обладнанням у стандартній конфігурації, яка інтегрується з іншими навігаційними системами і пристроями на судні. Стандартна конфігурація НIC ECDIS, як базовий елемент СППР, складається 3 рівня основного і допоміжного процесорних модулів, модуля введення-виведення даних від суднових датчиків, модуля обробки даних і засобів для відображення інформації, а також джерел безперебійного живлення для всієї НІС.

Рівень процесорних модулів зазвичай складається з комп'ютера, адаптованого для використання на морі, який служить місцем зберігання для карт $\mathrm{ENC}$, і за допомогою модуля введення-виведення отримує інформацію від датчиків корабля і представляє іï на засобах відображення. Обидва модуля обробки можуть незалежно виконувати всі функції HIC ECDIS в разі відмови одного з них. У разі одночасної роботи, вони працюють за принципом сервер-клієнт, і в будь-який момент часу стан серверного модуля обробки може бути переключено з одного модуля на інший модуль обробки. Частиною модуля введення даних від суднових датчиків може бути будь-який навігаційний пристрій або система, така як GNSS, ехолот, анемометр, AIS, і т.д., яке надає інформацію про різні поточні параметри судна. Всі ці дані, що надходять з суднових датчиків, обробляються в модулі обробки процесору.

Якщо взяти до уваги доступну інформацію, яку надає HICECDIS, то можна іiі розглядати як базовий елемент СППР на всіх етапах плавання судна, починаючи від базового надання доступної інформації до автоматичного відстеження руху корабля на будь- 
якому заданому маршруті. Основними принципами електронної навігації є при цьому обмін, аналіз, збір і зберігання даних, і можна стверджувати, що інформація і можливості іiі використання є ключем до успішного застосування електронної навігації на практиці [4-12]. Тобто, комбінація різних даних, отриманих з декількох взаємно незалежних джерел, вибір і реалізація відповідної математичної моделі підтримки прийняття рішення на основі цих даних, i можливості подання результуючої інформації дозволяють розглядати HIC ECDIS як базовий елемент в архітектурі СППР для безпеки навігації в рамках відповідної інформаційної технології.

Інформаційна технологія підтримки прийняття рішень передбачає принципово інший спосіб організації взаємодії оператора 3 HIC ECDIS. Рішення, вироблення якого і $є$ кінцева мета цієї технології, виходить за допомогою ітераційного процесу за

участю:

- СППР як об'єкта управління і для здійснення обчислювального процесу;

- оператора в ролі ланки керуючого, який повинен контролювати вхідні дані і оцінювати результат обчислень, отриманий з використанням СППР на основі HIC ECDIS.

Кожна СППР включає певні дані, які організовані в базу даних, мають відповідну модель опису даних і інтерфейс користувача, який допомагає оператору відстежувати і контролювати систему. Така організаційна структура створює основу для прийняття рішень в будь-який імовірній ситуації. 3 точки зору HIC ECDIS, основні компоненти CППР можуть бути представлені, як показано на рис. 2. Це структура СППР, яка використовує ресурси ECDIS для виконання необхідних функцій по безпечній навігації морських суден.
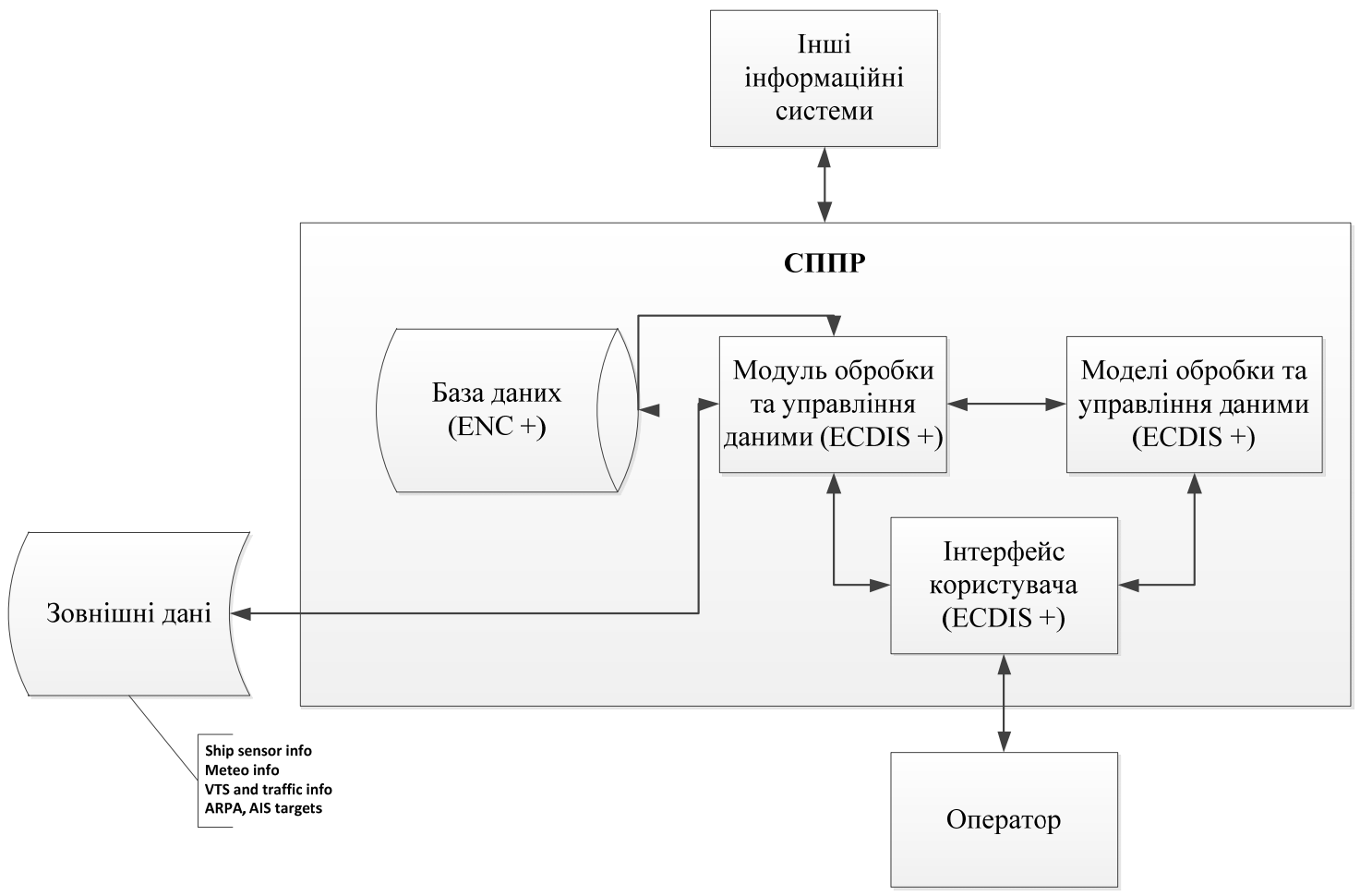

Рис. 2. Основні компоненти СППР на базі HIC ECDIS

Джерело: розроблено авторами.

Крім даних з навколишнього середовища судна (в першу чергу, інформації від суднових датчиків), ECDIS в своїх базах даних використовує також статичні дані, що, з точки зору часу, не є оптимальним рішенням. Беручи до уваги час, як важливий фактор, що впливає на весь спектр різних параметрів із зовнішнього середовища корабля, з'являється можливість створення інформації в реальному часі, яка надасть значний вплив на операції посадових осіб в навігації. При цьому, великий обсяг даних, зібраних в базі даних СППР, буде не тільки служити простим ïx нагромадженням. Метою є об'єднання всіх доступних даних в значущу інформацію в реальному часі, яка стане основою для прийняття відповідних дій в різних навігаційних ситуаціях. Збираючи всю доступну інформацію в середовищі корабля, доступну 3 зовнішніх і внутрішніх джерел, інтегруючи їх в базу даних і нові типи даних, аналіз і представлення цих даних у вигляді нової корисної інформації відкриває можливість для побудови СППР на основі концепції електронної навігації.

Цей підхід спрямований на те, щоб надати насамперед якісну інформацію, щоб правильно реагувати в потенційно небезпечних ситуаціях, замість того, щоб накопичувати цілий ряд даних, які іноді мають другорядне значення. 


\section{Висновки}

3 обов'язковим впровадженням ECDIS, електронна навігація також розвивається як концепція зберігання, обміну та інтеграції інформації між судами та береговими інституціями. 3 огляду на те, що інформація є головним елементом концепції електронної навігації і основою для прийняття рішень в повсякденному навігації, пропонується HIC ECDIS розглядати центральною системою, яка забезпечить таку інтеграцію і обмін інформацією. Такий підхід до архітектури СППР повністю фокусує увагу посадових осіб на HIC ECDIS як головне джерело навігаційних даних і інформації на борту судна. Зібрана інформація може надаватися таким чином, щоб найкраще описати поточну ситуацію навколо судна, беручи до уваги інші об'єкти, з якими судно взаємодіє або має тенденцію до взаємодії. Мінімум інформації, якою будуть завантажені посадові особи на даний момент, як і раніше залишається важливою проблемою, тому що немає єдиної думки про те, яка інформація важлива і як визначити її пріоритет. Для вирішення цієї проблеми також необхідно врахову- вати конкретні потреби кінцевих користувачів, беручи до уваги потенційні проблеми, що можуть виникнути під час різних ситуацій навігації.

Інтеграція інформації за допомогою НIC ECDIS, яку користувач отримує від інформаційних систем з материка, інших судів та інформації, отриманої від датчиків судна, в якісну інформацію та іiі відповідне представлення, створюють передумови для правильного прийняття рішень в щоденному рейсі судна. Така інтеграція інформації відкриває нові можливості для використання HIC ECDIS, наприклад, при представленні об'ємної навігації в CППР. Адаптація HIC ECDIS до вимог і потреб електронної навігації безпосередньо впливає на підвищення безпеки морського руху, яке буде проявлятися завдяки запобіганню морських аварій, запобіганню виходу суден на мілину, запобігання екологічних інцидентів і простоті отримання інформації при обміні іiї між судами, пошуковорятувальними службами і при відповідній підтримці 3 материка.

\section{Список літератури}

1. Вагущенко Л. Л. Судовые навигационно-информационные системы. Одесса : НУ “ОМА”, 2016. 238 с.

2. Bistrović M. Impact of E-Navigation on ECDIS Development as a Decision Support System. 2015. P. 30-39. URL: http://surl.li/alhqn (accessed 10.05.2021).

3. The admiralty vector chart service (AVCS) : web site. URL: https://www.martek-marine.com/shop/ecdis-charts/ (accessed 10.05.2021).

4. Вагущенко Л. Л. Судовые навигационно-информационные системы : 2-е изд. Херсон : Гринь Д.С., 2015. 400 с.

5. ЭКНИС Navmarine, версия 5.0.84. Полное руководство пользователя. Москва : Эксмо, 2012. 209 с.

6. Findings of Canadian E-Navigation User Needs Survey. 2009. 16 p. URL: https://waves-vagues.dfompo.gc.ca/Library/344822.pdf (accessed 10.05.2021).

7. Дакі О. А., Дорошева А. О., Іваненко В. М., Чебан В. І. Агентоорієнтована модель реалізації системи підтримки прийняття рішення безпеки судноводіння. Системи озброєння $і$ військова техніка. 2020. №3(63). С. 122-30. https://doi.org/10.30748/soivt.2020.63.18.

8. Страхов А. Ф. Автоматизированные измерительные комплексы. Москва : Энергоиздат, 1990. 216 с.

9. Grewal M. S., Weill L. R., Andrews A. P. Global Positioning Systems, Inertial navigation and integration. New York : Wiley, 2007. $416 \mathrm{p}$.

10. Соловьев И. Морская радиоэлектроника. Санкт-Петербург : Политехника, 2003. 185 с.

11. Дакі О. А. Метод розрахунку критерію чутливості контролю радіонавігаційних комплексів засобів водного транспорту. Наука $і$ техніка Повітряних Сил Збройних Сил Украӥни. $2019 . \quad$ № 2(35). С. $184-89$. https://doi.org/10.30748/nitps.2019.35.24.

12. Rogers R. M. Applied Mathematics in Integrated Navigation Systems. Reston : American Institute of Aeronautics and Astronautics, 2003. $351 \mathrm{p}$.

Надійшла до редколегії 10.08.2021

Схвалена до друку 16.11.2021

\section{Відомості про авторів:}

\author{
Якусевич Юрій Геннадійович \\ кандидат технічних наук доцент \\ доцент кафедри Дунайського інституту водного \\ транспорту Державного університету \\ інфраструктури та технологій, \\ Ізмаїл, Україна \\ https://orcid.org/0000-0002-5933-5417
}

\section{Information about the authors:}

\author{
Yuriy Yakusevych \\ $\mathrm{PhD}$ in Engineering Associate Professor \\ Associate Professor of the Danube Institute \\ of Water Transport of the State University \\ of Infrastructure and Technology, \\ Izmail, Ukraine \\ https://orcid.org/0000-0002-5933-5417
}


Тришин В'ячеслав Валентинович

старший викладач

Дунайського інституту водного транспорту Державного університету інфраструктури та технологій, Ізмаїл, Україна https://orcid.org/0000-0001-7562-2662

\section{Дорофсєва Зоя Яківна}

старший викладач

Дунайського інституту водного транспорту Державного університету інфраструктури та технологій, Ізмаїл, Україна https://orcid.org/0000-0003-3354-578X

\section{Vyacheslav Tryshyn}

Senior Lecturer of the Danube Institute of Water Transport of the State University of Infrastructure and Technology, Izmail, Ukraine https://orcid.org/0000-0001-7562-2662

Zoya Dorofyeyeva

Senior Lecturer of the Danube Institute of Water Transport of the State University of Infrastructure and Technology, Izmail, Ukraine https://orcid.org/0000-0003-3354-578X

\section{ПОСТРОЕНИЕ НАВИГАЦИОННОЙ СИСТЕМЫ СУДНА НА ОСНОВЕ СОВРЕМЕННЫХ ИНФОРМАЦИОННЫХ ТЕХНОЛОГИЙ}

Ю.Г. Якусевич, В.В. Тришин, З.Я. Дорофєєва

В статье рассматривается возможность применения информационных технологий в мониторинге движения судов для поиска новых решений на основе концепции электронной навигации. Внедрение электронной навигации требует адаптации существующих систем навигации и связи в этой новой концепции. Рассматриваются подходьл к разработке систем поддержки принятия решений на основе навигационно-информационной системы ECDIS из-за требований электронной навигации. Учитывая большое количество устройств и систем, используемых в навигации, адаптация навигационно-информационной системь ECDIS с требованиями электронной навигации имеет смьсл только при тщуательном понимании потребностей пользователя. Путем интеграции всей доступной информации, ее организации в базе данных и представление ее определенным образом создается платформа для принятия решений в повседневной навигации судна с использованием системы поддержки принятия решений. Поскольку применение навигационноинформационной системы ECDIS на борту стало обязательным и основным навигационным устройством судна, адаптация к требованиям электронной навигации означает превращение ее в базовый компонент соответствующей системы поддержки принятия решений.

Ключевье слова: Electronic Chart Display and Information System, навигационно-информационные системы, электронные карты, информационная технология, система поддержки принятия решений, морское судно.

\section{CONSTRUCTION OF A VESSEL NAVIGATION SYSTEM BASED ON MODERN INFORMATION TECHNOLOGIES}

Yu. Yakusevych, V. Tryshyn, Z. Dorofyeyeva

The paper discusses the possibility of using information technologies in monitoring the movement of vessels to find new solutions based on the concept of electronic navigation. The introduction of e-navigation requires the adaptation of existing navigation and communication systems to this new concept. Approaches to the development of a DSS based on the NIS ECDIS, taking into account the requirements of electronic navigation, are considered. Considering the large number of devices and systems used in navigation, the adaptation of the NIS ECDIS to the requirements of electronic navigation makes sense only with a thorough understanding of the user's needs. Adaptation of ECDIS NIS to the requirements and needs of electronic navigation directly affects the increase of maritime safety, which will be manifested by the prevention of maritime accidents, prevention of stranding, prevention of environmental incidents and ease of obtaining information when exchanging it between ships, search and rescue services, appropriate support from the mainland. By integrating all available information, organizing it in a database and presenting it in a certain way, a platform is created for making decisions in the daily navigation of a ship using DSS. This integration of information opens up new possibilities for the use of ECDIS NIS, for example, in the presentation of volumetric navigation in DSS. Since the use of the R / V ECDIS on board has become mandatory and has become the main navigation device of the vessel, adaptation to the requirements of electronic navigation means its presentation as a basic component of the corresponding DSS.

Keywords: Electronic Chart Display and Information System, navigation and information systems, electronic charts, information technology, decision support system, sea vessel. 